Vol. 5, No. 2, 2019

УДК 327.51

https://doi.org/10.23939/shv2019.02.001

\title{
PECULIARITIES OF USING INFORMATIONAL OPERATIONS BY THE INTERNATIONAL COALITION DURING THE IRAQ MILITARY CAMPAIGN IN 2003
}

\author{
Mykola Hetmanchuk \\ Lviv Polytechnic National University \\ ORCID: 0000-002-2627-8161 \\ hetmanchukm@ukr.net \\ Zoriana Zazuliak \\ Lviv Polytechnic National University \\ ORCID: 0000-0002-0098-9424 \\ zazuliak.zorian@gmail.com
}

(стаття надійшла до редколегї-25.09.2019 р., прийнята до друку - 25.10.2019 р.)

(C) Гетьманчук М., Зазуляк 3., 2019

The article analyzes the forms, methods and means of conducting informational operations at all stages of the Iraqi military campaign by the US-led international coalition in 2003. It is shown that the military campaign of the international coalition in Iraq of 2003 was characterized by the complex use of special informational operations in both political and military spheres: 1) overthrowing the dictatorial regime of Saddam Hussein in Iraq; 2) search and destruction of mass destruction weapons; 3) neutralization of activity and liquidation of the centers of the terrorist organizations «Army of Magdi», "Al - Qaeda» and others; 4) assisting the Iraqi people in building a democratic state. The practice of the military campaign in Iraq has shown that international coalition forces conducted informational operations of all kinds: 1) ones to ensure and support military operations; 2) ones to misinform the enemy; 3) special ones; 4) humanitarian ones. Special structures of the military contingents of the coalition carried out informational operations mainly at the operational and tactical levels. The experience of the military campaign in Iraq has shown that special ways of conducting informational operations have taken into account: a) content (stabilizing or destabilizing); b) social values (traditional or destructive); c) the nature of society (authoritarian, democratic).

Key words: international coalition, military campaign, Iraq, informational war, informational operation, informational weapon, terrorism.

\section{ОСОБЛИВОСТІ ПРОВЕДЕННЯ МІЖНАРОДНОЮ КОАЛІЦІЕЮ ІНФОРМАЦІЙНИХ ОПЕРАЦІЙ ПІД ЧАС ВОЄННОЇ КАМПАНІЇ В ІРАКУ У 2003 РОЦІ}

\author{
Микола Гетьманчук \\ Національний університет «Львівська політехніка» \\ ORCID: 0000-002-2627-8161 \\ hetmanchukm@ukr.net \\ Зоряна Зазуляк \\ Національний університет «Львівська політехніка» \\ ORCID: 0000-0002-0098-9424 \\ zazuliak.zorian@gmail.com
}

У статті досліджено форми, методи і засоби проведення інформаційних операцій на всіх етапах воснної кампанії в Іраку 2003 р. силами міжнародної коаліції на чолі із США. Показано, що воснна кампанія міжнародної коаліції в Іраку 2003 р. характеризувалася комплексним застосуванням спеціальних інформаційних операцій як у 
політичній, так і військовій сферах: 1) для повалення диктаторського режиму Саддама Хусейна в Іраку; 2) пошуку та знищення зброї масового ураження; 3) нейтралізації діяльності та ліквідації осередків терористичних організацій «Армії Магді», «Аль-Каїди землі Межиріччя» та інших; 4) надання допомоги іракському народові у розбудові демократичної держави. Практика воснної кампанії в Іраку засвідчила, що сили міжнародної коаліції проводили інформаційні операції всіх видів: 1) для забезпечення та підтримки військових дій; 2) для дезінформації противника; 3) спеціальні; 4) в гуманітарній сфері. Спеціальними структурами військових контингентів країн коаліції реалізовувалися інформаційні операції переважно на оперативному та тактичному рівнях. Досвід воснної кампанії В Іраку засвідчив, що спеціальні структури при проведенні інформаційних операцій враховували: а) контент (стабілізаційний чи дестабілізаційний); б) суспільні цінності (традиційні чи руйнівні); в) характер суспільства (авторитарний, демократичний).

Ключові слова: міжнародна коалічія, воєнна кампанія, Ірак, інформаційна війна, інформаційна операція, інформачійна зброя, тероризм.

The problem of «informational war», as well as the problem of «informational weapons», was first explored in the early 1980s. The American researcher T. Ron was one of the first authors who in 1976 introduced the term «informational war» and formulated its main reasons [Trebin 2005]. Ukrainian researchers emphasize that the direct precursors of the term «informational war» were the terms «psychological war», «political war», «psychological operation», «informational operation». Today, three main models for building informational operations are identified: 1) American, which is actively used for peaceful and military purposes; 2) British, which has relatively little practical implementation and application; 3) Russian (reflexive), designed to disorganize the enemy [Zhad'ko 2018; Pocheptsov 2015]. The Iraqi military campaign of 2003 was distinguished by its peculiarities in conducting informational operations (IO) on both sides. They were used by international coalition forces at all levels. The most successful IO in Iraq was conducted by specialists from the U.S., UK, Polish, Spanish, and Ukrainian peacekeeping contingents.

The official reason for the hostilities in Iraq was the alleged link between Saddam Hussein's regime and international terrorist groups, including the Al Qaeda movement, as well as the search and devastation of mass destruction weapons (chemical shells produced before 1991) [Derihlazova 2004]. The military campaign, which started on March 20, 2003, was conducted by military units of an international coalition from almost 40 countries - 225.000 of personnel, 610 tanks (430 U.S., 180 British), 400 aircraft and helicopters. On August 11, 2003 according to the Decree of the President of Ukraine «On sending peacekeeping contingent in the international peacekeeping operation in the Republic of Iraq», the Ukrainian military contingent has landed at the territory of Iraq, numbering 1680 people (19th separate battalion of radiation, chemical and biological protection and 5 th separate mechanized brigade of the Land Forces of the Armed Forces of Ukraine). The Decree of the President of Ukraine stated that the reason of Ukrainian troops to join the operation was the obligation of Ukraine, as a member of the international community, to advocate for world peace [Decree of the President of Ukraine «On sending...» 2003].

In the informational sphere the international coalition forces had the following tasks: 1) to form the necessary public opinion in the U.S., Arab countries and in the world as a whole; 2) to promote the activities of the international coalition forces; 3 ) to eliminate the possibility of supporting Iraq by other states; 4) to use the existing contradictions between the countries of the Arab world in the fight against Saddam Hussein's regime; 5) to misinform the Iraqi Armed Forces Command regarding military plans; 6) to undermine the confidence in President Saddam Hussein among the Iraqi population; 7) to support the resistance movement and assist the opposition forces in Iraq; 8) to convince the Iraqi population about the hopelessness of resistance to the forces of the international coalition [Volkovskyi 2003]. At the same time, special attention was paid to the forces of the international coalition to counteract international terrorism, which became a threat to the public and national security of the world community. Terrorism, both in its manifestations and in the problem of counteraction to it, was considered, above all, as a phenomenon of the informational space, the seizure of which became the main goal of terrorist organizations [Belonozhkin 2017; Harmashov 2005].

All IOs were conducted according to the same scheme: 1) the first stage (planning the operation, determining the feasibility of its implementation, goals, forces and means, methods of influence, target audience of influence); 2) the second stage (creation of an informational occasion - an event or «pseudo-event» that could be used to start the operation; 3) the third stage («unwinding» of the informational reason, using it to achieve the goals of surgery, formation or destruction of certain psychological stereotypes); 4) the fourth stage (withdrawal from the special operation or the securing stage, ensuring the planned completion of the propaganda campaign or due to an act of providence [Hetmanchuk 2008]. 
The system of the U.S. army ideological influence propaganda in Iraq was carried out by three separate structures that interacted with each other: 1) informational operations (IO); 2) public relations structure public information operations (PIO); 3) structure which cooperates with local (provincial) mass media.

Within the framework of IO, U.S. specialists aimed their activities at: organizing press-conferences, interviews, briefings with officials (divisional and brigades commanders etc.); broadcasting of radio programs, preparation of video reports, coverage of all military, humanitarian, political and administrative activities that were carried out in Iraq for the world media in the most favorable light for the United States and its allies. Specialists of this structure have been in constant contact with world agencies - CNN, Reuters, Associated Press, and French Press. The main purpose of this structure was to form a positive image of the coalition in the world;

The main task of the PIO was to establish links with local authorities, political, religious and civic organizations, business circles, intellectual elites, sheikhs (leaders of tribal communities). Traditionally, these representatives of the Iraqi elite held real power and influence. U.S. PIO specialists have been particularly successful in using methods of individual influence, both towards key figures in Iraq's political and military elites and towards ordinary citizens;

The third media structure together with the IO structure focused on local (provincial) media [Tkachuk, 2005]. The media played the key role in conducting the $\mathrm{IO}$, as it was evidenced. In the process of conducting IO, the experts professionally evaluated their informational weapons according to the quality of information and media (printed materials, audio, television and video recordings, radio, computer networks, cinema, theater, religious buildings) [Senchenko 2014].

The U.S. administration facilitated the restoration of local authorities by June 28, 2004 and the IO structures implemented the gradual deployment of a broadcasting studios network with translation capabilities of up to $100 \mathrm{~km}$ in major cities of Iraq. The U.S.-funded «Radio Liberty of Iraq», «Sawa» (Together), «Al-Muktabal», and «Nahraim» (Two Rivers) have actively started supporting the coalition forces. These types of IO can be categorized as «white» propaganda.

Experts referred to the work of Arab Radio Tikrit as «black» propaganda, as on February 2003 it assured listeners in their support of Saddam Hussein's regime, but within a few weeks they started criticizing the regime [Pontniere 2003]. Information for non-Iraqi remote areas was organized as follows: video booths were installed in central coffee shops, and PIO specialists supplied them with news and newspaper tapes.

The population of Iraq has been continuously exposed to psychological and informational influence through the U.S.-funded Iraqi informational network. It included the «Al-Iragiya» television company (which covered $85 \%$ of the population) and two radio stations [Zinko 2009].

Until 2003, under the regime of Saddam Hussein, researchers had private access to the Internet only at night and the number of visitors did not exceed 200 people [Chechelin 2013]. Therefore, 150 Internet cafes were opened in Baghdad by the end of 2003, and in August 2004 the Internet became available throughout the country [Zinko 2009]. It should also be noted that the terrorist organization Al-Qaeda has also used the Internet quite actively, but in order to create a negative image of the U.S. in the world and to recruit new members for its organization.

Working with young people and children has become an important task of the PIO structure. For this purpose, the experts explored youth problems and distributed youth magazines, brochures, children's books of propaganda content. Iraqi students from provincial educational institutions received internships at the universities of coalition countries, modernly-equipped free media centers were created throughout the country. Humanitarian assistance was provided to schools, universities, trade unions, public organizations, and people with disabilities, which were widely covered in the media.

Psychological operations (PSYOPS) were performed in Iraq by special groups (tactical psychological team - TPT), which were organized in all military units of the coalition. The task of these groups was to create and disseminate such motivational messages among extremist groups and the local population that would facilitate military and humanitarian operations. Materials for these groups were prepared at the Psychological Operations Center in Baghdad. In most cases, they used postcards and speakers. Most of the group consisted of 3-4 military personnel (sergeant or junior officer level), who generally had professional experience (Kosovo, Afghanistan, Somalia, etc.). These groups were armed with modern loudspeakers based on the Hummer car with the possibility of broadcasting radio messages for a distance of $1.5 \mathrm{~km}$. The car was equipped with a satellite navigation system, radio stations, a trailer with a cargo capacity of up to 1 ton (for transportation of printed materials, laptops, video cameras, digital recorders, printers and other property) [Hetmanchuk 2005]. 
The use of sound disinformation by the extremist armed groups has become very effective in Iraq. Yes, the sound of a flying helicopter, in the majority of cases, forced the fighters to cease fire, change positions and impersonate; the sounds of machine-gun bursts made them focus the fire in the right direction; the sounds of battle, the shouts of the wounded, the noise of tank engines and aircrafts often caused chaos and uncertainty among the militants. Practice has shown that the duration of the optimal broadcast time should not exceed 1-3 minutes, and the speed of the car should not be more than $5 \mathrm{~km}$ per hour. Radio propaganda, which contributed to the voluntary release of Iraqi servicemen, was also an effective tool. Later, four out of five Iraqi war prisoners stated that they were constantly listening to the translations of the «Voice of the Gulf» radio station broadcasted by specialists of the 4th group of the U.S. psychological operations [Pidlisnyi 2012].

Experts of IOs actively spread leaflets of various contents to both the population and Iraqi military personnel. Just before the fights on March 20, 2003, 40 million leaflets were dropped by Iraqi coalition air forces (5 million more than during the operation «Desert Storm») [Collins 2003]. The distribution of leaflets with the help of helicopters (up to 200 thousand leaflets per event) was especially often practiced.

Visual means of agitation and propaganda (leaflets, posters, booklets, newsletters) were actively developed. The works of local writers, poets, and artists were the basis of this printed production informational content. It was common to paint the walls of houses with propaganda plots, slogans, graffiti: «No terrorism!», «No war!», «Islam against terrorists and robbers!», «No weapons and violence!»

A considerable amount of experience in conducting IO was gained in Iraq by the Polish TPT groups, which had the same organizational structure as the U.S. units. All kinds of information activities, which were intended to destroy the stereotype of the «occupiers» in the eyes of the local population with its religious orthodoxy, were placed to one goal «We help you to build democracy». The activities of the Polish IO structures were focused on two areas: 1) forming a positive public opinion about the great powers helping Iraq; 2) creating preconditions in the informational space for economic penetration into the region.

As a part of the Polish military contingent, a whole team of civilian specialists (in military form) were brought to Iraq to carry out economic exploration of the region. Polish IO structures brought to Iraq a large number of T-shirts, baseball caps, pens, pencils, children's coloring books, calendars, stickers with Iraqi and Polish symbols (flags) and short inscriptions «We are not your enemies, we have come to rescue». It is also worth noting that officers and sergeants of Polish TPT groups were fluent in English and had psychological education [Hetmanchuk 2005]. Four groups have been set up in the Polish army according to NATO standards to organize and conduct IOs (120 militants in peacetime and 480 - during wartime) [Senchenko 2014].

Polish IO structures have proven to be professional in combating, so the Poles led the TPT groups division within the multinational division of the Center-South coalition forces. 27 officers of the Ukrainian peacekeeping contingent served at the headquarters of this division [Zinkovskyi 2012]. The TPT group at the division headquarters monitored the socio-political situation and the moral and psychological state of the population in the area the division responsibility, studied the directions, methods and consequences of the informational and psychological influence. It analyzed the transmission of informational broadcast through 4 television satellite channels; listened to and analyzed 4 radio programs with electronic media recordings; analyzed the Internet sources; created materials of informational and psychological influence. The typography of the group was able to print 120 thousand of simple leaflets and 130 thousand of colored ones in 8 hours [Tkachuk 2005]. The Polish contingent command was particularly concerned about the image of their country in the eyes of the Iraqi population and allies. American, Spanish, Ukrainian, and other TPT groups also acted in the same way.

Ukrainian military peacekeeping contingent controlled the Iraqi province of Wasit. It performed assignments in the cities of Al-Kuta, Suwaira, Babylon, Baghdad, Fort Badr and on the Iranian-Iraqi border. They have successfully: 1) established close links with local and foreign media in Al-Qut (province center); 2) conducted effective negotiations with more than 20 political, religious and public organizations; 3 ) until June 28, 2004, through negotiations established close contacts with the administration of the province, local police, units of the National Guard, educational institutions; 4) identified the problems of the region and the ways to solve them; 5) explored the attitude of the population toward the international coalition forces; 6) analyzed the peculiarities of illegal armed groups actions [Collins 2003; Leha 2014]. Ukrainian IO structures took an active part in the creation of Al-Kut TV, a local media center, and «Vasi Alyan» newspaper. In July 2004, the Iraqi government recognized these media sources as the best among the regional ones and even presented the Ukrainians with awards.

On August 28, 2004 at the conference of the IO structures in Baghdad, the department of $5^{\text {th }}$ Ukrainian 
united mechanized brigade IO, under the command of Lieutenant Colonel V. Kuzmin, took second place among the representatives of national peacekeeping contingents after Great Britain. Personal communication and cooperation with local media as methods of Ukrainian IO structure work, have been recognized as the best in the overall strategy of all international coalition IO structures [Ukrainian peacekeepers recognized... 2004].

Ukrainian IO structures constantly covered in the local media the process of providing humanitarian assistance to coalition countries, repaired and built schools, hospitals, explained the basic principles of democracy. Ukrainian command representatives' speeches aroused great interest in the local media and among the Iraqis, which contributed to the formation of a positive image of Ukraine and the coalition. Ukrainian peacekeepers have implemented 350 projects in Iraq on the economic revitalization of Washit province and the reconstruction of its infrastructure: 1) built 16 schools, repaired 7 kindergartens, 4 highways, 3 power lines, 4 water supply facilities, provided assistance to 40 thousand people; 2) trained 6,000 troops for the 3rd brigade of the Iraqi Armed Forces; 3) reconstructed forts for the border police, barracks and headquarters for Iraqi territorial defense units [Zinkovsky 2012]. Among the reasons that created difficulties to the activities of Ukrainian IO structures were the following: 1) language barrier (lack of Arabic-speaking translators with local dialect); 2) constant rotation of peacekeepers; 3) a limited number of specialists in the Ukrainian IO structure (4 servicemen could not fully perform propaganda around 1 million people in the province, at the same time in the British zone there were 200 IO specialists); 4) insufficient provision of means in conducting IO [Hetmanchuk 2005].

There were basically two extremist organizations responsible for the terrorist attacks in Iraq: 1) "As-Sadr» with its leader Muqtada as-Sadr. After the fall of Saddam Hussein's regime in April 2003, he created the religious and political movement «Jamaat al-Sadr al-Thani», and in July of the same year he created militarized organization «Magdie's Army»; 2) Al-Qaeda Iraqi unit «Al-Qaeda of the Inter-Riyadh land», which was responsible for numerous attacks that killed thousands of civilians [Volokhov, 2018]. The brutal murders of civilians in Iraq have led to the fact that many Sunni militants have begun to assist the coalition's forces in the fight against al-Qaeda [How Al-Qaeda Spread the World 2013].

Analyzing the extremist elements and terrorist organizations propaganda actions, they were most often conducted in the form of leaflets, appeals to the local population and the administration, speeches of mullahs and imams in mosques. In these actions, the main enemy of the Iraqis was the United States. The visual agitation of the militants was limited. Basically, these were portraits of religious and political figures with the inscriptions «Muktada - yes, yes!», «Long live Muktada!», etc. Also, Quranic quotations about Jihad were often found.

The key feature of Islamic propaganda was «bomb propaganda leaflet» (in order to prevent the destruction of such propaganda literature in the places of its spread land mines, anti-tank charges were laid). Such propaganda was not successful, but still the coalition forces gained some psychological advantage. In April 2004, a group of Iraqi political parties condemned the activities of the «Magdie Army» and the «As-Sadr».

Effective information activities by IO structures have led to the lack of support for the local Magdi Army in August 2004. If in April 2004 it was supported by half of the population in Al-Kuta and $40 \%$ sympathized them, then in August only $10 \%$ did [Hetmanchuk 2005]. In addition, IO structures have launched a successful campaign to discredit militants, skillfully using cases of looting.

The experience of peacekeeping campaign conducting in Iraq in 2003 testified some new approaches in conducting IO: 1) applying the transition of psychological operations mainly to informational ones; 2) informational support for the post-war conflict phase was as important as during the period of military operations; 3) for the first time in the military conflicts there was an active use of powerful forces and means of IO at the state and military levels; 4) the media has proven to be the most powerful tool for conducting IO; 5) the first successful experience in conducting IO performed by the Ukrainian Armed Forces.

Due to the participation of the Ukrainian military contingent in the military campaign in Iraq, in Ukraine the law on combating terrorism was quickly adopted and the Council of Europe Convention on the Prevention of Terrorism was ratified on 31.07.2006. In 2012 according to the Presidential Decree of December 29, 2012, the phenomenon of an informational war was defined, but later this document became invalid. Later, in the Strategic Defense Bulletin of Ukraine dated 6.06.2016, there is no definition of information war at all, and its interpretation has been moved into the rank of discussion issues.

\section{ЛІТЕРАТУРА}

Белоножкин, В., Остапенко, Г. (2017). Информационные аспекты противодействия тероризму. Москва: Горячая линия-Телеком.

Волковский, Н. (2003). История информационных войн. Санкт-Петербург: ООО «Полигон». 
Волохов, В. (2018). Ірак: велика гра Муктади асСадра. Незалежний аналітичний центр геополітичних досліджень «Борисфен Інтел». Отримано $3 \mathrm{http}$ : // bintel.com.ua /uk/ article /06_18_Irag/

Гармашов, I. (2005). Сутність сучасного тероризму i його основні характеристики. Персонал: журнал інтелектуальної еліти, 6. Отримано з http://www.personal. in.ua/ article.php? ida $=21$.

Гетьманчук, Н. (2005). Деятельность структур информационно- психологических операций на примере военной кампании в Ираке. СБ Украины, Международное сотрудничество в сфере борьбы $с$ терроризмом $c$ применением бактериологического, химического и ядерного оружия: Материаль научно-практического семинара, 57-66. Яворовский полигон ВС Украины.

Гетьманчук, М. (2008). Особливості проведення інформаційно-психологічних операцій в Іраку багатонаціональними стабілізаційними силами. Психологічні аспекти національної безпеки: Тези Другої міжнародної науково- практичної конферениії, 60-62. Львів: ЛьвДУВС

Жадько, В. (2018). Гібридна війна і журналістика. Проблеми інформаційної безпеки: навчальний посібник. Київ: Видавництво НПУ імені М. П. Драгоманова.

Дериглазова, Л. (2004). Война в Ираке 2003 г. как продолжение войны США против терроризма. Отримано з: https: cybereninka. ru /article/n/ vojna-v-irake-2003-g-kakprodolzhenie-vojny-ssha-protiv-terrorizma

Закон України «Про боротьбу 3 тероризмом» № 638-IV від 20.03.2003 p. (2003). Отримано з: https: zakon.help /law/638-IV/edition 28.07.2016/

Зінько, С. (2009). Країни Близького Сходу в сучасних міжнародних інформаційних відносинах. Львів: Ліга-прес.

Зіньковський, С. (2012). Український миротворчий контингент у Республіці Ірак. Вісник Харківського національного університету імені В. Н. Каразіна. Серія: Історія. Українознавство: історичні та філософські науки, 15, 55-61.

Лега, А. (2011). Дії українських миротворчих підрозділів в Іраку (2003-2005). Сумська старовина, № 3334, 13-18. Отримано 3: http://starovyna. sumdu.edu.ua/wpcontent/uploads/2014/06/Лега.pdf

Підлісний, А. (2012). Зміст і динаміка інформаційно-психологічного впливу США у військових операціях в Іраку (1990-2010рр.). Вісник Начіонального університету «Львівська політехніка»: Держава $і$ армія, вun. 724, 221-228.

Почепцов, Г. (2015). Сучасні інформаційні війни. Київ: Видавничий дім «Києво-Могилянська академія».

Сенченко, М. (2014). Латентна світова інформаційна війна. Київ: ФОП Стебеляк.

Ткачук, П., Черник, П. (2005). Діяльність структур інформаційно-психологічних операцій (на прикладі Іраку). Матеріали міжвузівської науково-практичної конференції: Україна на рубежі XXI ст.: суспільно-політичні трансформації - це геополітичні виклики сучасності, 8 жовтня, 69-84.
Требин, М. (2005). Войны XXI века. Москва: АСТ; Минск.: Харвест.

Указ президента України «Про направлення миротворчого контингенту для участі України у міжнародній миротворчій операції в Республіці Ірак». (2003). Офіційний вісник Украӥни. № 24 (27 червня).

Українські миротворці в Іраку визнані. (2004). Отримано 3: https:/ua.korrespondent.net/ukraine/247028ukrayinski-mirotvorci-v-iraku-viznani-krashchimi.

Чечелін, О. (2008). Хронологія війни в Іраку в контексті інформаційних воєн. Медіакритика, № 3 . Отримано 3: https://www.media-krytyka.info /drukovani/ khronolohija-vijny-v-iraku-v-konteksti-informatsijnyhvojen.html

Як «Аль-Каїда» поширилася світом. (2013). Отримано 3: https://www.bbc.com /news/2013/08/ 130807_al_gaeda_worldwide_ag.

Collins, S. Mind Game. (2003). NATO Review. Summer.

Pontniere, P. (2003). U.S. Launches Psyops War Against Irag. New America Media, Mar. 13.

\section{REFERENCES}

Belonozhkin, V., Ostapenko, G. (2017). Information aspects of counter-terrorism. [In Russian]. Moscow: Horyachaya liniya-Telecom.

Collins, S. Mind Game. (2003). NATO Review. Summer.

Decree of the President of Ukraine «On sending a peacekeeping contingent for Ukraine's participation in an international peacekeeping operation in the Republic of Iraq» (2003). Official Bulletin of Ukraine, No. 24 (June 27).

Derihlazova, L. (2004). The War in Iraq 2003 as a Continuation of the US War on Terror. [In Russian]. Retrieved from: https: cybereninka. ru/article /n/ military-v-irake-2003-gkak-prodolzhenie-military-ssha-anti-terrorism

Garmashov, I. (2005). The Essence of Modern Terrorism and Its Main Characteristics. [In Ukrainian]. Personnel: The Journal for Intellectual Elite, 6. Retrieved from http://www.personal.in.ua/ article.php?ida=21

Hetmanchuk, M. (2005). Activity of the Structures of Information and Psychological Operations on the Example of Military Campaign in Iraq. [In Ukrainian]. Security Council of Ukraine, International Cooperation in the Field of Combating Terrorism with the Use of Bacteriological, Chemical and Nuclear Weapons: Proceedings of the Scientific and Practical Seminar, 57-66. Yavoriv Polygon of the Ukrainian Military Forces.

Hetmanchuk, M. (2008). Features of Conducting Information and Psychological Operations in Iraq by Multinational Stabilization Forces. [In Ukrainian]. Psychological Aspects of National Security: Abstracts of the Second International Scientific and Practical Conference, 60-62. Lviv: Lviv Internal Affairs Department.

How Al-Qaeda Spread the World. (2013). [In Ukrainian]. Retrieved from: https://www.bbc.com/news/2013/08/130807_al_gaeda_worldwi de_ag 
Leha, A. (2014). Actions by Ukrainian Peacekeeping Units in Iraq (2003-2005). [In Ukrainian]. Sumy Relic of the Past, No. 33-34, 13-18. Retrieved from: http://starovyna.sumdu. edu.ua/wp-content/uploads/ 2014/06/Lega.pdf

Law of Ukraine «On Combating Terrorism» No. 638IV of 20.03.2003 (2003). [In Ukrainian]. Retrieved from: https: zakon.help/law/638-I/ edition7/28/2016/

Pidlisnyi, A. (2012). Content and Dynamics of US Psychological Influence in US Military Operations in Iraq (1990-2010). [In Ukrainian]. Bulletin of the Lviv Polytechnic National University: State and Army, № 724, 221-228.

Pontniere, P. (2003). U.S. Launches Psyops War against Iraq. New America Media, Mar. 13.

Pocheptsov, G. (2015). Modern Information Wars. Kyiv: Publishing House «Kyiv-Mohyla Academy».

Senchenko, M. (2014). Latent World Information War. [In Ukrainian]. Kyiv: FOP Stebelyak.

Tkachuk, P., Chernik, P. (2005). Activity of Structures of Information and Psychological Operations (On the Example of Iraq). [In Ukrainian]. Proceedings of the Inter-University Scientific-Practical Conference: Ukraine at the Turn of the 21st Century: Socio-Political Transformations are Geopolitical Challenges of the Present, 69-84.

Trebin, M. (2005). Twentieth Century Wars. [In Russian]. Moscow: AST; Minsk: Harvest.
Ukrainian peacekeepers recognized in Iraq. (2004). Retrieved from: https://ua.korrespondent.net/ukraine/247028ukrayinski-mirotvorci-v-iraku-viznani-krashchimi.

Chechelin, O. (2008). The Chronology of the Iraq War in the Context of Information Wars. [In Ukrainian]. Media Critics, №3. Retrieved from https://www.media-krytyka.info /drukovani/ khronolohija-vijny-v-iraku-v-kontekstiinformatsijnyh-vojen.html

Volkovskyi, N.(2003). History of Information Wars. [In Russian]. Saint-Petersburg: LLC «Polygon».

Volokhov, V. (2018). Iraq: The Great Game of Muktadi Ace-Sadra. [In Ukrainian]. Indepent Analytical Centre of Geopolitical Reseachers «Borysphen Intel». Retrieved from http://bintel.com.ua/uk/article/06_18_Irag/

Zinko, S. (2009). Middle East Countries in Contemporary International Information Relations. [In Ukrainian]. Lviv: League-Press.

Zinkovsky, S. (2012). Ukrainian Peacekeeping Contingent in the Republic of Iraq. [In Ukrainian]. Bulletin of the VN Kharkiv National University Karazin. Series: History. Ukrainian Studies: Historical and Philosophical Sciences, 15, 55-66.

Zhadko, V. (2018). Hybrid War and Journalism. Information Security Issues: A Tutorial. Kyiv: M. P. Drahomanov Publishing House of NPU. 